\title{
THE POLITICAL ECONOMY OF GROWTH MANAGEMENT IN OREGON: A HISTORICAL REVIEW
}

\author{
Gerrit J. Knaap*
}

\section{Introduction}

Growth management exploded as an issue in urban and regional policy in the late 1960 s and early 1970 s. Where growth was once a desideratum, concerns over the quality of the environment, population growth, and public service costs produced a mandate to control growth in many urban areas. Exemplary of the policy debate around growth management that had developed by the mid-70s was the set of papers, edited by Scott et al (1975), entitled The Management and Control of Growth. This set of papers identified Ramapo, New York, Salem, Oregon, Boulder, Colorado, Petaluma, California, and Boca Raton, Florida, as pioneers of urban growth management.

As the focus of urban policy began to change from economic development to growth management, so also did the focus of state-level policy. Fostered by many of the same concerns that fostered urban growth management, a "quiet revolution" began to take hold at the state level (Bosselman and Callies, 1971). This revolution returned much of the power to control land use and thereby growth to state governments. It developed in part to coordinate growth management efforts between urban governments and to control growth in areas outside the influence of urban governments-especially in rural areas and environmentally sensitive areas along coastlines and riverbeds. California, Florida, Hawaii, Oregon, and Vermont were some of the pioneers in this effort (Healy and Rosenberg, 1979).

This paper explores the political economy of statewide growth management in Oregon. The paper addresses the following issues: 1) What were the political forces in Oregon that produced a statewide effort to manage and control growth? 2) How has the Oregon system of growth management evolved over time and 3) Does the political support for a mature growth management system differ from the political support that fostered its birth? An analysis of these issues offers insights not only into the political economy of growth management in Oregon, but also into the existing and perhaps the future of growth management systems elsewhere.

*Assistant Professor of Urban and Regional Planning, University
of Illinois, Urbana, IL 61801

\section{The Movement to Control Growth}

Shortly after the birth of state and urban growth management systems, social scientists developed theories to explain why such systems developed. The forms of growth management vary widely. Urban governments enacted zoning codes, building moratoria, urban growth boundaries, and population caps; state governments created statewide land use systems, farm-tax deferral programs, and regional planning commissions. Although ideological perspectives vary widely, most theories of growth controls at all levels of government contain a common thread; namely, they suggest that growth controls serve the upper class at the expense of the lower class. Writers addressing urban growth controls include White (1978), Edel (1972), Logan (1978), and Mills (1979); writers addressing statewide growth controls include Bosselman and Callies (1971), Nourse (1977), and Walker and Heiman (1981). But in spite of the widely held perspective of growth management as an instrument of the upper class, empirical support for this class-based view has been thin.

The attack on the class-based theory of urban growth management has been waged largely from the campuses of the University of California with data from California. Gottdiener and Neiman (1981), Protash and Baldassare (1983), and Baldassare (1984), all found the support for urban growth controls in California weakly correlated with measures of social class. Connerly and Frank (1986) found no relationship between measures of class and support for growth controls in a survey of Florida residents, and Clark (1979) found little correlation between a state-level growth management index and social indexes of statewide populations.

In rejecting the class-based theories of growth management the empirical evidence has not rejected the hypothesis that support for growth management is divided by social strata. On the contrary, the evidence strongly suggests that support for growth management is correlated with the occupation, income, education, housing-ownership status, gender, and location of the population. Instead the class-based theory of growth management is rejected because the social divisions that stratify the support for growth management are only weakly correlated with the social divisions that stratify class. 
The evidence concerning the political movement to control growth in Oregon largely is consistent with the evidence from elsewhere. Little (1974), who documented the passage of the landmark Oregon land use bill, found sharp divisions in the support for land use controls in that state. Little found that legislators from the Willamette Valley (the highly populated urban area of the State) voted 49 to nine for the land use statutes while legislators from outside the Willamette Valley voted 21 to nine against them.

Medler and Mushketel (1979) analyzed a referendum to end state growth management in 1976, only two years after the program began. They also surveyed residents of Eugene, Oregon. They found a positive correlation between support for the program (a vote against the repeal) and socio-economic characteristics (specifically, income, and education) at the county level. At the urban level, however, they found support for the program negatively correlated to income. From this Medler and Mushketel concluded: "Overall it appears that social class, as a contextual variable, is a relevant variable. It seems to be the broader differences between cities and counties that affect voter sentiment, rather than the situation of the individual...Simply put, on average the better off counties and cities favor land use planning while the less well off reject it...." (Medler and Mushketel, 1979, p. 347-49)

In sum, analyses of the movement to control growth in Oregon found significant social divisions in political support. Support for growth control was greatest in the Willamette Valley, where incomes are higher, the population lives in urban areas and works at urban occupations. But in the urban areas, support for the program was negatively related to income. This evidence provides support for the class-based theory of growth management only if class is so defined; but the evidence provides little support for the notion that the movement to control growth in Oregon was divided along traditional class lines. Thus the early evidence from Oregon was quite similar to that from elsewhere around the nation.

In a recent commentary on the political economy of growth management, Gottdiener (1983) raised an issue more germane to the study of growth management than the definition of class. Gottdiener suggests that there is a difference between support for growth control and support for growth management. Growth management he defines as "the actions of local state bureaucrats in managing the tenor of development;" growth control he defines as "an organized collective action of some kind supported by local residents that affects the political process in some way" (Gottdiener, 1983, p. 565-6.) In short, Gottdiener argues that a movement to control growth develops out of social forces that are manifest in a political context.
Growth management, which occurs after a political resolution to control growth, is the administrative process of controlling growth. This insightful distinction opens two new avenues for research beyond analysis of the movement to control growth: namely, what are the political forces that shape the administrative process of controlling growth, and does the support for a mature growth management system differ from the support that brought the system into place? These issues can be addressed best by analyzing a mature growth management system. The Oregon statewide land use system offers an opportunity for such analysis.

\section{Growth Management in Oregon}

Growth management in Oregon takes place primarily via its nationally acclaimed land use program. The Oregon land use program is well known and is described in detail elsewhere (Leonard, 1983; DeGrove, 1984; Rohse, 1987). In response to rapid population growth, resource depletion, and environmental degradation, the 1973 Oregon Legislature passed Senate Bill 100. In brief, Senate Bill 100 required all cities, counties, and special districts to complete comprehensive plans for all land within their jurisdiction; it created the Land Conservation and Development Commission (LCDC), and its administrative arm, the Department of Land Conservation and Development (DLCD); it authorized the LCDC to formulate mandatory statewide land use planning goals and guidelines; and it required that $L C D C$ acknowledge all plans as conforming with the statewide goals and guidelines. Currently DLCD has acknowledged all of the 277 local comprehensive plans and has entered the post-acknowledgement phase. This phase involves ensuring that all local land use decisions are consistent with acknowledged plans.

\section{The Dynamics of Growth Management}

In an early analysis of the politics of growth management, Godwin and Shepard (1975) presented a framework for analyzing the dynamics of state-level growth management policies. Their purpose was to predict winners and losers in growth management regulation. They proceeded by classifying regulatory systems, identifying the affected interest groups, and formulating hypotheses about the development of state growth management policies. This section of the paper reviews the literature on the administrative aspects of growth management in Oregon since 1976 to examine the validity of the hypotheses offered by Godwin and Shepard. The review concludes with a reflection on the issue raised by Gottdiener.

Godwin and Shepard began with a review of the 
typology of regulatory systems developed by Lowi (1964) and by Salisbury and Heinz (1970). The typology divides regulatory policies into distributive, self-regulatory, redistributive, and regulatory classes. In brief, distributive policies draw resources form the general public and distribute these resources to selected groups; self-regulatory policies draw power from the general public and distribute this power to selected groups; redistributive policies draw resources form specific groups and redistribute these resources to selected other groups; and regulatory policies take power from disparate individuals and groups and redistribute these powers to a centralized authority. Godwin and Shepard suggested that redistributive and regulatory policies are difficult to enact because they identify winners and losers. For this reason, they argued, where state land use policies are enacted, they generally are self regulatory. ${ }^{1}$

Next, Godwin and Shepard described regulatory politics as a politics of pluralism-politics dominated by organized interest groups-and identified three interest groups as dominant in the politics of state land use policies. Interest group A includes developers, land speculators, builders, and mortgage financiers who prefer only local, if any, control over land use. Interest group B includes highly organized groups interested in the preservation of environmental quality; these groups prefer state and higher level planning systems. Interest group $\mathrm{C}$ includes an amorphous coalition of homeowners and neighborhood groups who prefer decentralized planning to preserve the character of their social environment. According to Godwin and Shepard, these three interest groups share similar upper-class origins but disagree over which elements of the status quo should receive greater protection. Based on the typology of regulatory policies and the interests and interactions of the three interest groups, Godwin and Shepard formulated six hypothesis about the development and internal dynamics of statewide growth management systems. Each of these is discussed in turn below.

Hypothesis 1: State land use policies will deal mainly with procedural rather than allocative outcomes.

Although Godwin and Shepard wrote before LCDC adopted the 19 goals and guidelines later set forth, hypothesis one remains generally true. The 19 goals and guidelines established procedural, rather than allocative rules for local governments to follow in the construction of comprehensive plans. ${ }^{2}$ A cursory review of the land use goals and guidelines reveals that the Oregon land use policy contains no quantitative limits, formulas, or specifications; instead the goals and guidelines stipulate only what must be planned, what must be considered in formu- lating the plans, and when the plans must be completed (Oregon LCDC, 1976). Allocative outcomes thus are established through the acknowledgement process rather than through a statewide political process (Rohse, 1987). According to Godwin and Shepard, this was necessary to avoid decisions on substantive issues upon which the three interest groups disagreed. Specifying allocative outcomes beforehand would weaken the coalition required to gain the support necessary for starting the process.

Hypothesis 2: To the extent that state land use policies include statements of goals, the goals will incorporate the interests of all three of the Issue Publics [interest groups] without attempting to solve inconsistencies among competing objectives.

The validity of hypothesis two in Oregon also is readily apparent from a cursory review of the $19 \mathrm{goals}$ and guidelines. The goals provide a bone for each of the three interest groups: a housing goal for the development groups; a conservation goal for the environmental groups; and a growth management goal for the home-owners groups. Inconsistencies among the goals also are readily apparent. For example, the plans must preserve forest land while stimulating the economy. The plans must contain urban growth within urban growth boundaries while providing ample housing for all segments of the population. The plans must facilitate transportation while encouraging energy conservation (Oregon LCDC, 1976). Even after considerable political compromise many of these issues ultimately were settled in court (Leonard, 1983). As noted by Godwin and Shepard, the juxtaposition of the terms conservation and development in the title of the lead state agency is a good example of the validity of hypothesis two.

Hypothesis 3: The procedural elements of initial state land use legislation will be more self-regulatory (decentralized) than regulatory (centralized) in form.

The validity of hypothesis three also is fairly self evident from the structure of the Oregon land use system. Existing land use authority is delegated to local governments; local governments construct, implement, and enforce their own land use plans (Rohse, 1987). Such decentralization is necessary at first, according to Godwin and Shepard, to maintain the support of the development and homeowners groups. New land use authority-e.g. authority over such environmentally sensitive areas as beaches and river basins-is assumed by the state to gain the support of the environmental groups.

Hypothesis 4: As state land use policies develop and 
change over time they will shift from the hypothesized initial self-regulatory (more decentralized) policy toward regulatory (more centralized) policy.

The foresight of Godwin and Shepard is most apparent in this hypothesis. Although Godwin and Shepard formulated hypothesis four before local comprehensive planning had even begun, they predicted that local governments would have inadequate time and resources to complete the plans on schedule. They were right. Acknowledgment not only has slowed the planning process, the DLCD also has been able to influence the substance of local comprehensive plans via self-interpretation of the statewide goals and guidelines. Through the acknowledgement process, the DLCD developed increasingly specific and substantive policies to control land use at the local level (DeGrove and Stroud, 1980). This has been particularly true of the urban growth boundary (Knaap and Nelson, 1988). As a result, the state-level regulatory agency has been able to determine the substance of much of the growth management policy in Oregon.

Although the DLCD has influenced the content of local comprehensive plans substantially, as Godwin and Shepard predicted, it has not participated as actively in the enforcement of the plans. On the contrary, suggests Liberty (1988), the DLCD has become more occupied with self preservation than with its original mission, leaving the "foxes to guard the chickenhouse." Liberty suggests that the power of DLCD (or its exercise) in the enforcement of local plans has weakened severely in recent years. In support of this position, a recent memorandum on local farm use decisions by Ross (1986), who then directed DLCD, concluded by stating: "the current pattern of approvals represents either a conscious or unconscious attempt to solve a locally perceived 'lot-of-record' problem regardless of state law or local acknowledged plans and land use regulations."

Thus, the pendulum swings both ways. At first, local governments lead the planning process through the construction of comprehensive land use plans. Subsequently, the State land use authority is able to use the acknowledgement process to dictate the substance of local comprehensive plans. The responsibility for implementing and enforcing the comprehensive plans belongs to local governments, however. Thus far, local implementation and enforcement have not satisfied the expectations of the DLCD.

Hypothesis 5: The allocations involved in state land use policies will be distributive in nature.

At the beginning, the interplay of interest-group politics was much as predicted by Godwin and Shepard.
The environmentalist groups preferred a centralized system of growth management; the neighborhood groups preferred a decentralized system; and the development groups opposed growth management altogether. In addition, several other interest groups representing farmers, county governments and general business also played active roles. The development groups, however, were divided; the neighborhood groups were so amorphous as to be ineffective; the business groups and the farmers were outnumbered (DeGrove, 1984). As a result, a committee bill creating a powerful, though ill-defined and decentralized, system of growth management was passed-just as predicted. With the passage of time, however, internal dynamics changed the weak decentralized system into a strong centralized one and the economy in which the system operated changed from boom to bust, so that serving the interests of all active interest groups became impossible.

In such instances as the compensation of owners of farm land with farm-tax deferrals, the provision of grants to cities for constructing land use plans, and the permitting of higher density construction inside growth boundaries to offset construction bans outside growth boundaries, hypothesis five holds (DeGrove, 1984). State growth management provided benefits for particular groups at the expense of the general public. But there have been cases of direct conflicts of interest between groups in which the DLCD (or LUBA, the state land use court) had to identify distinct winners and losers. Suburban interests clearly lost when the DLCD decided against exclusionary zoning codes and in favor of high-density housing (1000 Friends of Oregon and Ray C. Hallberg v. City of Lake Oswego, LCDC 78-024); city governments clearly lost when the DLCD decided against expansive urban growth boundaries and in favor of farmland preservation (1000 Friends of Oregon v. Metropolitan Service District, LCDC 78-039); the forest products industry clearly lost on decisions to limit uses of forest lands (DeGrove, 1984, p. 280). On various occasions, then, a compromise simply could not be bought with general tax dollars. Thus, as decisions affecting competing interest groups had to be made, the allocations became more redistributive than anticipated.

When the land use program became more redistributive (having to identify winners and losers) the interest group alignment changed. The environmentalist groups remained strongly supportive, and the support of the League of Cities had been bought by intergovernmental grants. A powerful new interest group entered the fray in 1975. With the aid of former Governor Tom McCall, "1000 Friends of Oregon" was formed as an independent 'watchdog' organization to give "the people of Oregon a powerful tool to help America's leading state land use program succeed" (1000 Friends of Oregon, 1982). The 
organization began as a small group of land-use attorneys, but has since become a prime force in the design and implementation of land use law in Oregon.

This unique interest group has been very active in offering testimony and taking administrative and judicial appeals to further its causes, causes which first included only resource and environmental conservation. More recently, however, 1000 Friends has taken on other causes, including advocacy for low cost housing. As a result, the base of support for 1000 Friends in particular, and for the entire land use program in general, broadened considerably. After supporting the losing side in the 1976 referendum to repeal the land use statutes, and after viewing the effectiveness with which 1000 Friends manipulated the program to further its causes, the development groups decided to play rather than fight the system. Thus, 1000 Friends now has representatives of business and industry on its board of directors. Armed with this new financial support, 1000 Friends recently has pressed at length for the implementation of the housing goal. Thus in 1982, largely due to the ability to make the program work in its favor, the development lobby strongly supported statewide growth management (Knaap, 1987b).

In retrospect, the interest group politics of the Oregon statewide growth management system began as predicted by Godwin and Shepard, but as the system changed, so did the position of interest groups. Groups that once opposed statewide growth regulation found that regulation can be beneficial when regulatory politics are played effectively. Other groups found that a vaguely defined, decentralized growth management system can develop into a sharply defined centralized growth management system -one that can severely harm proprietary interests even in the face of political struggle. Exceptions to hypothesis five thus have been documented, rendering the hypothesis accurate only in part.

Hypothesis 6: The level of social justice will be decreased in society if statewide land use policies and politics continue on their present course.

Hypothesis six clearly is the most judgmental and therefore the most controversial. Hypothesis six is based largely on the validity of the earlier hypotheses. That is, if state regulatory politics are a politics of intra-class interest groups (hypothesis two), and if participating interest groups are seldom penalized without compensation (hypothesis five), then only unrepresented groups-specifically the poor-suffer costs. In short, hypothesis six returns, in a more elaborate form, to the class-based theory of growth management.

The available evidence, however, suggests that hypothesis five is only partly accurate; thus, hypothesis six also is at best only partly accurate. The evidence from Oregon does not confirm that players of regulatory politics never suffer losses nor that the poor and other less organized interests groups are entirely unrepresented. City governments, resource-based industries, and local land owners all have suffered significant losses, as indicated above. The farmers groups, the service industries, and the homebuilders have won significant battles. ${ }^{3}$ Further, it is not clear that the poor always have suffered from these allocative outcomes. The urban poor clearly benefit from decisions against exclusionary housing policies. The rural poor could benefit from farm-tax deferrals. And the working poor may benefit from growth in the service industries. No hard evidence is available to document the gains of the poor, but there is evidence that the poor hold perceptions of gains.

Knaap (1987a) analyzed popular support for statewide growth management shortly after the 1982 referendum to repeal statewide growth management. Because he disaggregated the referendum results at both census tract and county levels, the results obtained by Knaap are comparable to those of Medler and Mushketel. As did Medler and Mushketel, Knaap found support for growth management sharply divided between the Willamette Valley and other regions of the State. Support for the program was much stronger in the Willamette Valley. Also as did Medler and Mushketel, Knaap found greater support for the system among renters than among homeowners. Support for the system was related positively to income at the county level but related negatively at the census-tract level.

The interpretation of the difference in results between county and urban levels, however, differs between Knaap and Medler and Mushketel. Medler and Mushketel discounted the less aggregated results in favor of the more aggregated results, arguing that "it appears to be the relative wealth of one's environment, not one's personal wealth that has an effect on support for land-use planning in Oregon" (Medler and Mushketel, 1979, p.346). Knaap provided strong evidence that the relationship between income and support for the program at the urban level was negative. Thus Knaap suggested that neither the positive relation between income and support for growth management at the county level, nor the negative relation between income and support for growth management at the census tract level could be dismissed. Instead, Knaap interpreted the mixed results as implying that the support for growth management was greater in the higher-income, urbanized counties of the Willamette Valley, but that within the Willamette Valley support for growth management was not greater among the upper class. Knaap interpreted these results and the result that the support for growth management was greater among renters than among homeowners 
as evidence that low income residents and renters supported the program because of its progress on housing. ${ }^{4}$ The evidence provided by Knaap and his interpretation of it raise considerable doubt as to the accuracy of hypothesis six.

\section{Summary and Conclusions}

This paper analyzed the political economy of growth management in Oregon. The paper began with a review of the literature on growth management within and outside of Oregon. The review uncovered consistent evidence that popular support for controlling growth varies by social strata, but that these strata do not match the divisions typically used to define social classes. Further, the review revealed a potentially important distinction between support for a movement to control growth and support for a mature growth management system. The paper then examined the evolution of the growth management system in Oregon in the context of the framework offered by Godwin and Shepard.

The review of the literature provided considerable support for several hypotheses offered by Godwin and Shepard. As predicted, the state-level growth management statutes enacted in Oregon prescribed more procedure than substance, and the statutes were vague and often inconsistent. The process of defining substance began at the local level but over time became increasingly centralized at the state level. The review did not support all of the Godwin and Shepard hypotheses, however. After the acknowledgment phase, the substantive aspects of growth management once have become decentralized; the number and variety of politically active interest groups made purely distributive allocation impossible; and not all impacts of growth management have been harmful to the poor.

As in the growth management program initially analyzed, the Godwin and Shepard framework was better able to specify administrative procedure than allocative outcome in the Oregon case. The accuracy of the Godwin and Shepard hypotheses concerning administrative procedure suggests that knowledge about interest group politics enables social scientists to make reasonably accurate predictions about the substance (or lack thereof) of public policies. But the inaccuracies of hypotheses about the allocative outcomes of growth management policies suggest that knowledge about interest group politics today is a poor predictor of interest group politics-and, hence, of allocative outcomes-tomorrow. Contrary to the expectations of Godwin and Shepard, there is little evidence to support the hypothesis that growth management policies benefit elite groups at the expense of the poor-even after the growth management system has had time to mature.
Finally, in spite of differences in interpretation, in spite of controversy concerning the definition of class, and in spite of interest group posturing, studies of the popular support for growth management in Oregon six years apart have produced consistent findings. Therefore it appears that the popular support for the movement to control growth in Oregon differs little from the support for growth management.

\section{Notes}

${ }^{1}$ Godwin and Shepard defined the Oregon land use program as self regulatory because they viewed the program as upsurping property rights and distributing those rights to a limited set of Issue Publics (interest groups).

${ }^{2}$ The land-use goals and guidelines include 1. citizen involvement, 2. the land use planning process, 3. agricultural lands, 4. forest lands, 5. open spaces, 6. air, water, and land quality, 7. natural hazards, 8. recreation, 9. the economy, 10. housing, 11. public facilities, 12. transportation, 13. energy conservation, 14. urbanization, 15. the Willamette River greenbelt, 16. estuarian resources, 17. coastal shorelands, 18. beaches and dunes, 19 . ocean resources.

${ }^{3}$ Based on campaign contributions, Knaap (1987b) found a difference in support for growth management between resourcebased and service industries. Resource-based firms are defined as firms that base their location decisions principally on the location of primary resources; service firms are labor-intensive firms that base their location decisions primarily on the availability of amenities for their employees.

${ }^{4} \mathrm{~A}$ reviewer suggested that much of the controversy about land use control concerns property rights. This finding supports that hypothesis. However, the argument that the poor are not necessarily harmed, and may benefit from land use controls, is enhanced in a property-right framework.

\section{References}

Baldassare, M. "Predicting Local Concern about Growth: The Roots of Citizen Discontent,"Journal of Urban Affairs, 4:3949, 1984.

Bosselman, F. and D. Callies. The Quiet Revolution in Land Use Control, Prepared for the U.S. Council on Environmental Quality, Washington, D.C.: U.S. Printing Office, 1971.

Clark, S. "Determinants of State Growth Management Policies," Policy Studies Journal, 7,4:753-62, 1979.

Connerly, C. and J. Frank, "Predicting Support for Local Growth Controls," Social Science Quarterly, December, 573-86, 1986.

DeGrove, J. M. Land Growth and Politics. Chicago, Illinois: Planners Press, American Planning Association, 1984. and N. Stroud. The States and Urban Strategies, U.S. Department of Housing and Urban Development, Washington, DC: U.S. Printing Office, 1980.

Edel. M. "Planning, Market, or Warfare? Recent Land Use Conflict in American Cities," in M. Edel and J. Rothenberg 
(ed.s) Urban Economics. New York, NY: McMillan, 1972.

Godwin, K. and W. Shepard, "State Land Use Policies: Winners and Losers," Environmental Law, V5:703-26, 1975.

Gottdiener, M. "Some Theoretical Issues in Growth Control Analysis," Urban Affairs Quarterly, 18:565-69, 1983. and M.Neiman, "Characteristics of Support for Local Growth Control," Urban Affairs Quarterly, 17:55-73, 1981.

Healy, R. and J. Rosenberg. Land Use and the States. 2nd ed. Baltimore, Maryland: Johns Hopkins University Press, 1979.

Knaap, G. J. “Self-Interest and Voter Support for Oregon's Land Use Controls," Journal of the American Planning Association, 53,1:92-97, 1987a.

"Social Organization, Profit Cycles, and Statewide Land Use Controls in Oregon: Welcome to Oregon, Enjoy Your Visit," Journal of Applied Behavioral Science, 23,3:371-86, $1987 \mathrm{~b}$.

and A. C. Nelson, "The Effects of Regional Land Use Control in Oregon: A Theoretical and Empirical Review," The Review of Regional Studies, 18,2: 37-46.

Leonard, J. H. Managing Oregon's Growth. Washington DC: The Conservation Foundation, 1983.

Liberty, R. L. "The Oregon Planning Experience: Repeating the Success and Avoiding the Mistakes," presented at the Conference on the Chesapeake Bay Critical Area Protection Program, June, 1988.

Little, C. E. The New Oregon Trail: An Account of the Passage of State Land-use Legislation in Oregon. Washington, DC: The Conservation Foundation, 1974.

Logan, J. "Growth, Politics and the Stratification of Places," American Journal of Sociology, 84,2:405-15,1978.

Lowi, T.J. American Business, Public Policy, Case Studies, and
Political Science, World Politics 16, 677-715, 1964.

Medler, J. and A. Mushketel, "Urban-Rural Class Conflict in Oregon Land Use Planning," Western Political Quarterly, September, 1979.

Mills, E. "Economic Analysis of Urban Land Use controls," in P. Mieszkowski and M. Straszheim (eds) Current Issues in Urban Economics. Baltimore, MD: Johns Hopkins University Press, 1979.

Nourse, H. "The Political Economy of Land Use Legislation." Unpublished Manuscript, 1977.

1000 Friends of Oregon, "Report for the Seventh Year: 19751982," Portland, OR, 1982

Oregon Land Conservation and Development Commission. Statewide Goals and Guidelines. Salem, OR, 1976.

Protash, W. and M. Baldassare, "Growth Policies and Community Status: A Test and Modification of Logan's Theory," Urban Affairs Quarterly 18:397-412, 1983.

Rohse, M. Land Use Planning in Oregon, Corvallis, OR: Oregon State University Press, 1987.

Ross, J. F. Memorandum to the Joint Legislative Committee on Land Use, Department of Land Conservation and Development, November, 1986.

Salisbury and Heinz, "A Theory of Policy Analysis and Some Preliminary Application," in Policy Analysis in Political Science. I. Sharkansky (ed) 1970.

Scott, R. A. (ed) Management and Control of Growth. Washington, DC: The Urban Land Institute, 1975.

Walker, R. and M. Heiman, "Quiet Revolution For Whom?" Annals of the Association of American Geographers, 71,6883,1981 .

White, M. "Self Interest in the Suburbs: The Trend Toward NoGrowth Zoning," Policy Analysis, 1978. 